\title{
Evaluation of the long-term compressive strength development of the sewage sludge ash/metakaolin-based geopolymer
}

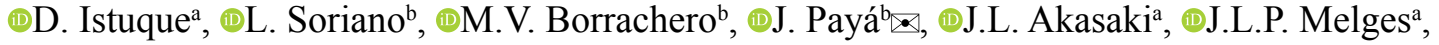 \\ (1) M.M. Tashima ${ }^{a}$ \\ a. Faculdade de Engenharia de Ilha Solteira, Universidade Estadual Paulista (UNESP), (Ilha Solteira-SP, Brazil) \\ b. ICITECH - Instituto de Ciencia y Tecnología del Hormigón, Universitat Politècnica de València (UPV), (Valencia, Spain) \\ 凶jpaya@cst.upv.es
}

Received 23 October 2020

Accepted 22 March 2021

Available on line 30 July 2021

\begin{abstract}
This paper aimed to evaluate the long-term compressive strength development of the sewage sludge ash/metakaolin (SSA/MK)-based geopolymer. SSA/MK-based geopolymeric mortars and pastes were produced at $25^{\circ} \mathrm{C}$ with different SSA contents (0 - 30 wt.\%). Compressive strength tests were run within the 3-720 curing days range. A physicochemical characterisation (X-ray diffraction and scanning electron microscopy) was performed in geopolymeric pastes. All the geopolymeric mortars presented a compressive strength gain with curing time. The mortars with all the SSA evaluated contents $(10,20,30$ wt.\%) developed a compressive strength over $40 \mathrm{MPa}$ after 720 curing days at $25^{\circ} \mathrm{C}$. The maximum compressive strength of the mortars with SSA was approximately $61 \mathrm{MPa}(10 \mathrm{wt} . \%$ of SSA), similarly to the reference mortar (100\% MK-based geopolymer). The microstructure analyses showed that the SSA/MK-based geopolymer presented a dense microstructure with N-A-S-H gel formation.
\end{abstract}

KEYWORDS: Alkali-activated cement; Metakaolin; Compressive strength; Mortar; Scanning electron microscopy.

Citation/Citar como: Istuque, D.; Soriano, L.; Borrachero, M.V.; Payá, J.; Akasaki, J.L.; Melges, J.L.P.; Tashima, M.M. (2021) Evaluation of the long-term compressive strength development of the sewage sludge ash/metakaolin-based geopolymer. Mater. Construcc. 72 [343], e254.

RESUMEN: Evaluación de la resistencia a compresión a largo plazo de geopolímeros producidos con metacaolín y ceniza de lodo de depuradora. En este estudio se evaluó la resistencia a compresión a largo plazo de geopolímeros con metacaolín (MK) y ceniza de lodo de depuradora (SSA). Se estudiaron morteros y pastas de geopolímeros SSA/MK con distintas proporciones de SSA $(0-30 \%)$ curados a $25^{\circ} \mathrm{C}$. Se determinaron resistencias a compresión en el intervalo de 3 a 720 días. La caracterización de pastas se realizó por medio de difracción de rayos X y microscopia electrónica de barrido. Todos los morteros desarrollaron ganancia de resistencia a compresión a lo largo del tiempo. Después de 720 días de curado, todos los morteros con SSA (10, 20 y 30\% en peso) presentaron resistencias superiores a $40 \mathrm{MPa}$. El mortero con $10 \%$ de SSA mostró el mayor valor de resistencia a compresión ( $\sim 61$ $\mathrm{MPa}$ ), alcanzando un valor similar al reportado para el mortero con $100 \% \mathrm{MK}$. El análisis de pastas mostró una microestuctura densa, con formación de gel N-A-S-H.

PALABRAS CLAVE: Cementos de activación alcalina; Metacaolín; Resistencia a compresión; Mortero; Microscopía electrónica de barrido.

Copyright: C2021 CSIC. This is an open-access article distributed under the terms of the Creative Commons Attribution 4.0 International (CC BY 4.0) License. 


\section{INTRODUCTION}

In a global scenario, the building construction sector's sustainable development has been seriously tracked. In fact, Portland cement (PC) is the most widely used material worldwide after water(1), and is composed primarily of non-renewable raw materials like limestone and clay (2). The production of this material means that cement industries are responsible for almost $8 \%$ of the world's $\mathrm{CO}_{2}$ emissions (2, $3)$. Therefore, more sustainable cementitious materials than PC cement are required to minimize this environmental issue. This is the reason why several researchers have studied alkali-activated and geopolymeric binders $(4,5)$.

Geopolymers are aluminosilicate binders with a low calcium content that yield a tridimensional-molecular structure in a high alkaline environment $(6,7)$. One of the most widely used manufactured precursors to produce geopolymer is metakaolin (MK) (8), although several agricultural and industrial waste types have been used; i.e. fly ash, rice husk ash, sugar cane bagasse ash, catalytic cracking catalyst residue, etc. (9-14). The inclusion of these residues in geopolymeric matrices is an essential advantage for geopolymer production because they emit less $\mathrm{CO}_{2}(15)$.

Generally speaking, the composition of these residues is siliceous or aluminosiliceous, which is fundamental for the geopolymeric reaction (16). The literature has specifically pointed out the incorporation of sewage sludge ash (SSA) into the geopolymer based on its physicochemical characteristics (17), apart from its environmental-friendly immobilization needed. Such residue, SSA, comes from incinerating sewage sludge generated during wastewater treatment. Its global generation is estimated at 1.7 million tonnes annually, with an increasing trend (18). This residue is mainly composed of $\mathrm{SiO}_{2}$, $\mathrm{CaO}, \mathrm{Al}_{2} \mathrm{O}_{3}, \mathrm{Fe}_{2} \mathrm{O}_{3}, \mathrm{P}_{2} \mathrm{O}_{3}$ and $\mathrm{SO}_{3}$, with an average content of $34.0 \%, 15.8 \%, 12.8 \%, 11.4 \%, 10.8 \%$ and $5.2 \%$, respectively $(18,19)$. Mineral phases as quartz $\left(\mathrm{SiO}_{2}\right)$, calcium phosphate $\left(\mathrm{Ca}\left(\mathrm{PO}_{4}\right)_{2}\right)$, calcite $\left(\mathrm{CaCO}_{3}\right)$, and hematite $\left(\mathrm{Fe}_{2} \mathrm{O}_{3}\right)$ are the most common ones found in the SSA composition $(18,20)$. According to the reports found in the literature, the amorphous content of SSA is largely varied, being found values in a range of $35 \%-75 \%$ (21). The specific gravity, BET specific surface area, and Blaine fineness of SSA vary in a range of 1.8-2.9, 2500-23100 $\mathrm{m}^{2} / \mathrm{kg}, 500-3900 \mathrm{~m}^{2} / \mathrm{kg}$, respectively (21). The average bulk density of SSA is $805 \mathrm{~kg} / \mathrm{m}^{3}$, which is a low value due to its porous particles (21). Given these physicochemical characteristics, SSA has been evaluated as raw material to produce blended PC, mortars, bricks, ceramics and glass $(19,22-28)$. Geopolymer systems seem to be another sustainable alternative for the immobilization of SSA. However, such an SSA application has not yet been properly explored, being found a few studies focused on this field (29-31).

Yamaguchi and Ikeda (29) reported a binary geopolymer produced by fly ash and SSA. At room temperature, this system had setting problems, and its compressive strength was inadequate at high temperatures $\left(80^{\circ} \mathrm{C}\right)$. However, the work by Istuque et al. (30) on another binary system reported promising results for a geopolymer produced by SSA and MK (SSA/MK-based geopolymer), with 10 wt.\% SSA and 90 wt. $\%$ MK cured at room temperature $\left(25^{\circ} \mathrm{C}\right)$ for 7 days. According to these authors, the SSA/MK-based geopolymer presented a similar compressive strength $(\approx 28 \mathrm{MPa})$ to the geopolymer reference, which composed only MK as a precursor. In another study, Istuque et al. (31) demonstrated how the SSA/MK-based geopolymer (10 wt.\% SSA and 90 wt. $\%$ MK) was activated by an activating solution with a $\mathrm{NaOH}$ concentration of 8 mol. $\mathrm{kg}^{-1}$ and an $\mathrm{SiO}_{2} / \mathrm{Na}_{2} \mathrm{O}$ molar ratio of 1.6 , which reached compressive strength to about $50 \mathrm{MPa}$ after 14 curing days at $25^{\circ} \mathrm{C}$. Nevertheless, their study reported research only into the mechanical development of the SSA/MK-based geopolymer for up to 180 curing days with low SSA content in the geopolymer composition (10 wt.\%). It would be interesting to increase the SSA content by replacing MK because this last component is a synthetic material that requires the use of non-renewable raw material and a considerable power supply (32); moreover, it is desirable to increase the content of SSA in the mixtures because immobilization will be a key issue in the SSA sustainable management.

Therefore, this work aimed to evaluate the compressive strength development of the SSA/MKbased geopolymer with different SSA contents $(0$, 10,20 and $30 \mathrm{wt} . \%$ ) cured at room temperature $\left(25^{\circ} \mathrm{C}\right)$ from 3 to 720 curing days. The mineralogy of geopolymeric pastes was investigated by X-ray diffraction (XRD), as well as the microstructure by scanning electron microscopy (SEM).

\section{EXPERIMENTAL PROCEDURES}

\subsection{Materials}

\subsubsection{Sewage sludge ash production}

Dried-granular sewage sludge, collected at a wastewater treatment plant (Serviço Municipal Autônomo de Água e Esgoto - SEMAE) in São José do Rio Preto city, SP, Brazil, was incinerated by a process called uncontrolled autocombustion in a cylindrical oven (200-liter volume). About $20 \mathrm{~kg}$ of dry sewage sludge were placed inside the oven. Only 1 minute of gas fire was necessary to start the combustion process. A thermocouple was placed in 
the center of the oven to record combustion temperature. After $15 \mathrm{~h}$, the combustion process ended and about $8.6 \mathrm{~kg}$ of SSA was obtained $(43 \%$ of the dry sewage sludge mass). Figure 1 shows the maximum average temperature of $774^{\circ} \mathrm{C}$, which was generally reached after $3 \mathrm{~h}$ of combustion. The ash (SSA) from the uncontrolled combustion was ground for $50 \mathrm{~min}-$ utes at an SSA/ball weight ratio of 0.10 . The milled SSA had a mean particle diameter of $20.28 \mu \mathrm{m}$, with $\mathrm{d}(0.1), \mathrm{d}(0.5)$ and $\mathrm{d}(0.9)$ being $1.58 \mu \mathrm{m}, 11.17 \mu \mathrm{m}$ and $52.45 \mu \mathrm{m}$, respectively. As can be seen in Table 1, SSA was mainly composed of $\mathrm{SiO}_{2}(38.28 \%)$ and $\mathrm{Al}_{2} \mathrm{O}_{3}(35.47 \%)$. In accordance with the XRD pattern of SSA, which was showed in Figure 5, quartz $\left(\mathrm{SiO}_{2}\right)$, anhydrite $\left(\mathrm{CaSO}_{4}\right)$ and hematite $\left(\mathrm{Fe}_{2} \mathrm{O}_{3}\right)$ were the main secondary phases. The insoluble residue content of SSA was $27.20 \%$, that since the sum of $\mathrm{SiO}_{2}(38.28 \%), \mathrm{Al}_{2} \mathrm{O}_{3}(20.72 \%)$ and $\mathrm{Fe}_{2} \mathrm{O}_{3}(11.27 \%)$ percentages from the SSA chemical composition was $70.17 \%$, and considering that the crystalline phase dissolution during the insoluble residue test is very low, could be inferred that at least significant percentage of the $\mathrm{SiO}_{2}$ was amorphous, as well as a considerable amount of $\mathrm{Al}_{2} \mathrm{O}_{3}$. The presence of amorphous phases in the SSA was pointed out by the slight deviation of the baseline between $18-32^{\circ} 2 \theta$ in the XRD pattern of SSA (See section 3.2.2.).

\subsubsection{Other materials}

MK was supplied by Metacaulim do Brasil ${ }^{\mathrm{TM}}$ to produce geopolymeric pastes and mortars, whose chemical composition is presented in Table $1 . \mathrm{NaOH}$ pellets (98\% of purity) and sodium silicate solution (waterglass, 61.4\% $\mathrm{H}_{2} \mathrm{O}, 29.7 \% \mathrm{SiO}_{2}$ e $8.9 \% \mathrm{Na}_{2} \mathrm{O}$ )

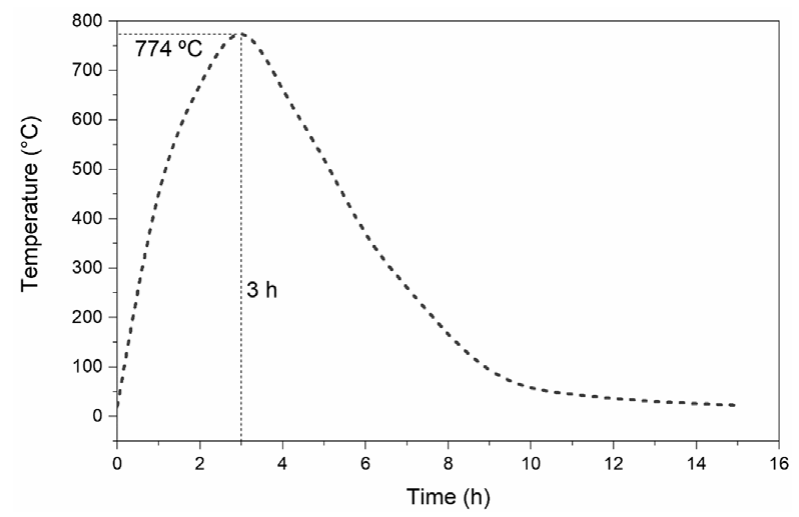

FIGURE 1. Temperature profile during the uncontrolled autocombustion of the dried-granular sewage sludge. were used to prepare the activating solution. Water was employed to adjust the water/binder ratio (binder $=\mathrm{MK}+\mathrm{SSA}$ ) of the geopolymeric pastes and mortars. Siliceous sand from Castilho city - SP, Brazil, was obtained to produce the geopolymeric mortars with a fineness modulus of 2.05 and a specific gravity of $2.67 \mathrm{~g} / \mathrm{cm}^{3}$.

\subsection{Producing geopolymeric pastes and mortars}

This study was divided into two steps (see Figure 2). In Step 1, the optimum $\mathrm{NaOH}$ concentration was achieved for the mortars with $10 \mathrm{wt} . \%$ of SSA and 90 wt. $\%$ of MK cured at 3 and 7 days at room temperature $\left(25^{\circ} \mathrm{C}\right)$. Activating solutions with different $\mathrm{NaOH}$ concentrations and $\mathrm{SiO}_{2} / \mathrm{Na}_{2} \mathrm{O}$ molar ratio

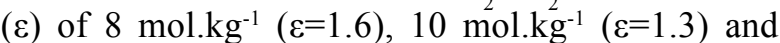
12 mol. $\mathrm{kg}^{-1}(\varepsilon=1.0)$ were prepared. The waterglass/ binder mass ratio was set at 0.78 for all the mortars assessed in Step 1. A previous study (31), which evaluated the influence of the $\mathrm{SiO}_{2} / \mathrm{Na}_{2} \mathrm{O}$ molar ratio for the mortars containing $8 \mathrm{~mol} . \mathrm{kg}^{-1}$ of $\mathrm{NaOH}$, established that a $\mathrm{SiO}_{2} / \mathrm{Na}_{2} \mathrm{O}$ ratio of 1.6 offered the best compressive strength results.

With the optimum $\mathrm{NaOH}$ concentration, the influence of SSA content $(10,20,30 \mathrm{wt} . \%$ replacing $\mathrm{MK}$ ) on the long-term compressive strength of the MK-based geopolymeric mortars was assessed in Step 2. Compressive strength tests were carried out at $3,7,28,90$ and 720 curing days at $25^{\circ} \mathrm{C}$ (climatic chamber, relative humidity of $95 \%$ ). X-ray diffraction (XRD) and scanning electron microscopy (SEM) analyses were conducted to corroborate the mechanical results.

The dosage of each geopolymeric mortar in Steps 1 and 2 are shown in Table 2. The nomenclature for the mortars from Step 1 was adopted: MKx $y(\varepsilon)$, where $x$ represents the percentage of SSA, $y$ represents the $\mathrm{NaOH}$ concentration, and $\varepsilon$ represents the $\mathrm{SiO}_{2} / \mathrm{Na}_{2} \mathrm{O}$ molar ratio. The nomenclature for the mortars from Step 2 was simplified to $\mathrm{MK} x$, considering that all of them present the same values of $\mathrm{NaOH}$ concentration and $\varepsilon$ according to the given results from Step 1. In both Steps 1 and 2, all the geopolymeric mortars were prepared by maintaining the water/binder and sand/binder mass ratios at 0.6 and 2.5, respectively (31). Precursors (MK and SSA) were homogeneously mixed before adding the activating solution, which was cooled to room temperature $\left(25^{\circ} \mathrm{C}\right)$. After obtaining a homogeneous

TABLE 1. Chemical composition of MK and SSA (wt.\%).

\begin{tabular}{cccccccccccccccc}
\hline Oxides $(\%)$ & $\mathrm{SiO}_{2}$ & $\mathrm{Al}_{2} \mathrm{O}_{3}$ & $\mathrm{Fe}_{2} \mathrm{O}_{3}$ & $\mathrm{P}_{2} \mathrm{O}_{3}$ & $\mathrm{CaO}$ & $\mathrm{SO}_{3}$ & $\mathrm{TiO}_{2}$ & $\mathrm{MgO}$ & $\mathrm{K}_{2} \mathrm{O}$ & $\mathrm{Na}_{2} \mathrm{O}$ & $\mathrm{Others}$ & $\mathrm{LOI}$ \\
\hline $\mathrm{MK}$ & 58.39 & 35.47 & 2.71 & - & 0.01 & - & 1.51 & 0.3 & 1.44 & - & 0.07 & 0.10 \\
\hline $\mathrm{SSA}$ & 38.28 & 20.72 & 11.27 & 7.28 & 5.51 & 4.18 & 3.73 & 1.91 & 0.73 & 0.70 & 1.97 & 3.72 \\
\hline
\end{tabular}


geopolymeric paste, sand was gradually added. The whole mechanical mixing process took 5 minutes. The geopolymeric mortars were molded in prismatic molds $\left(4 \times 4 \times 16 \mathrm{~cm}^{3}\right)$ and left for 1 minute on the vibration table $(35 \mathrm{~Hz})$ to release any incorporated air. The geopolymeric mortars were demolded after $24 \mathrm{~h}$ and stored in the climatic chamber until testing ages were reached.

\subsection{Compressive strength tests}

Compressive strengths were measured by an EMIC Universal machine according to UNE 1961:2018 (33). A device to apply the load in a $4 \times 4 \mathrm{~cm}^{2}$ area on two opposite sample faces was used in these tests. Compressive strength was calculated as the average of at least five values.

\subsection{Characterization of geopolymeric pastes}

The characterization of the geopolymeric pastes ( $\mathrm{MK}+\mathrm{SSA}+$ activating solution) based on the XRD and SEM analyses were carried out for the selected geopolymeric pastes assessed in Step 2 (see Figure 2 ). The mix proportion was the same as that used to prepare mortars without adding sand. A Shimadzu
XRD-6000 system was employed to obtain the XRD patterns within a $2 \theta$ range of $5-60^{\circ}$ in an angle step of $0.02^{\circ}$ and a step time of $1.20 \mathrm{~s} / \mathrm{step} . \mathrm{Cu}-\mathrm{K} \alpha$ radiation and an Ni filter were used at a voltage of $30 \mathrm{kV}$ and a current intensity of $40 \mathrm{~mA}$. The SEM images were taken by a ZEISS microscopic (model EVO LS15) from the fractured surface pastes covered with gold.

\section{RESULTS AND DISCUSSION}

\subsection{The results obtained from Step 1: selection of the optimum $\mathrm{NaOH}$ concentration}

\subsubsection{Compressive strength}

In Step 1, three different $\mathrm{NaOH}$ concentrations (8 mol.kg- $(\varepsilon=1.6), 10$ mol.kg-1 $(\varepsilon=1.3), 12$ mol.kg$(\varepsilon=1.0))$ in the activating solution were evaluated in the geopolymeric mortars with $10 \mathrm{wt} \%$ SSA and 90 wt. \% MK. The compressive strengths of those geopolymeric mortars cured for 3 and 7 days at room temperature are depicted in Figure 3.

The increasing $\mathrm{NaOH}$ concentration lowered the compressive strength of the SSA/MK-based geopolymeric mortars for both curing times ( 3 and 7 days). The mortars prepared using the $8 \mathrm{~mol}^{\mathrm{kg}} \mathrm{kg}^{-1}$

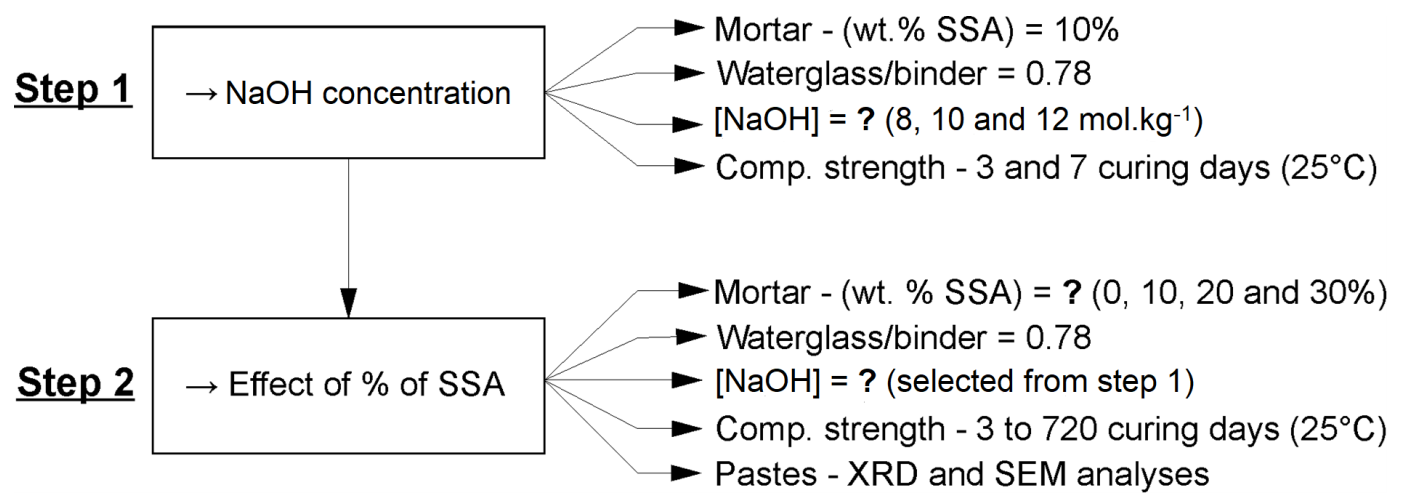

Figure 2. Methodology carried out in this study.

TABLE 2. Dosage of the geopolymeric mortars for step 1 and step 2.

\begin{tabular}{|c|c|c|c|c|c|c|}
\hline & & \multicolumn{2}{|c|}{ Binder } & \multicolumn{2}{|c|}{ Activating solution } & \multirow{2}{*}{ water/binder } \\
\hline & & MK (wt.\%) & SSA (wt.\%) & {$[\mathrm{NaOH}]$} & $\varepsilon$ & \\
\hline \multirow{3}{*}{ Step 1} & MK10 8 & & & 8 mol.kg-1 & 1.6 & \multirow{7}{*}{0.6} \\
\hline & MK10 10 & 90 & 10 & 10 mol. $\mathrm{kg}^{-1}$ & 1.3 & \\
\hline & MK10 12 & & & $12 \mathrm{~mol} . \mathrm{kg}^{-1}$ & 1.0 & \\
\hline \multirow{4}{*}{ Step 2} & MK0 & 100 & - & \multirow{4}{*}{\multicolumn{2}{|c|}{$[\mathrm{NaOH}]-\varepsilon$ from Step 1}} & \\
\hline & MK10 & 90 & 10 & & & \\
\hline & MK20 & 80 & 20 & & & \\
\hline & MK30 & 70 & 30 & & & \\
\hline
\end{tabular}


$\mathrm{NaOH}$ and $\varepsilon=1.6$ (MK10 8(1.6)) activating solution yielded the highest compressive strengths (30.9 and $31.9 \mathrm{MPa}$ at 3 and 7 days, respectively) compared to the other geopolymeric mortars. The literature reports that a $\mathrm{NaOH}$ concentration of approximately $8 \mathrm{M}$ is often used to produce MK-based geopolymers $(34,35)$. Kuenzel et al. (36) assumed that the $\mathrm{NaOH}$ concentration around $8 \mathrm{M}$ is enough for a proper dissolution of the reactive phases of metakaolinite. Moreover, it is well-known that as higher the $\mathrm{NaOH}$ concentration, faster is the MK geopolymerization, though a higher geopolymerization rate could lead to a lower polycondensation degree of the geopolymer, affecting the compressive strength development (37). The findings herein agree with such understanding. Hence, the dissolution of the amorphous phase of the system SSA/MK at $8 \mathrm{~mol}$. $\mathrm{kg}^{-1} \mathrm{NaOH}$ lead to a proper geopolymerization ratio, which results in higher compressive strength development. At the highest $\mathrm{NaOH}$ concentration $(12$ mol. $\left.\mathrm{kg}^{-1}\right)$, the compressive strength loss (3.8MPa), after 7 curing days, could be related to somewhat zeolite formation from the geopolymer matrix, which can occur for MK-based geopolymer systems even at room temperature (38). The following evaluations proposed in Step 2 were made with the geopolymeric mortars and pastes using the activating solution of 8 mol.kg ${ }^{-1} \mathrm{NaOH}(\varepsilon=1.6)$.

\subsection{The results obtained from Step 2: influence on SSA percentage}

All the evaluations in Step 2 were carried out with the geopolymeric pastes and mortars using an activating solution of $8 \mathrm{~mol} \cdot \mathrm{kg}^{-1} \mathrm{NaOH}(\varepsilon=1.6)$, varying the content of SSA in 10 wt.\% (MK10), 20 wt.\% (MK20), and 30 wt.\% (MK30).

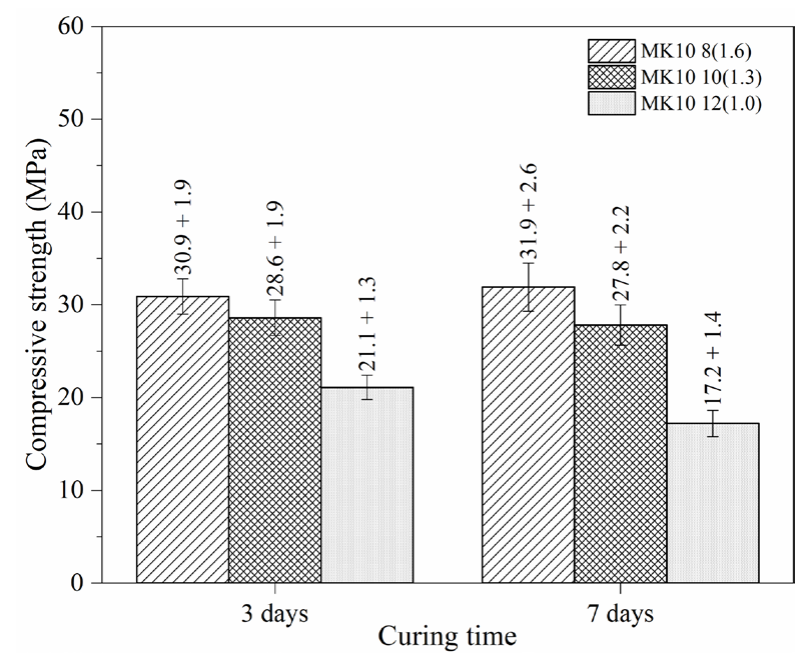

FIGURE 3. Compressive strength of the geopolymeric mortars with $10 \mathrm{wt} . \%$ SSA and $90 \mathrm{wt} . \%$ MK cured for 3 and 7 days at room temperature and different $\mathrm{NaOH}$ concentrations.

\subsubsection{Compressive strength}

The compressive strength of geopolymer mortars MK0, MK10, MK20 and MK30 at 3, 7, 28, 90 and 720 days were measured and are depicted in Figure 4. The geopolymeric mortar containing no SSA (MK0) content was set as a reference.

The reference geopolymeric mortar (MK0) presented a higher compressive strength for all the curing times ( 3 to 720 days), except for sample MK10, whose compressive strength was similar at 720 days. The compressive strength of the MK0 mortar was 66.9 $\pm 2.9 \mathrm{MPa}$, while that recorded for the MK10 mortar was $60.7 \pm 4.3 \mathrm{MPa}$, both recorded at 720 days. According to the Tukey test, the difference between the average compressive strength of these mortars (MK0 and MK10) was not significant at the 0.05 level.

Furthermore, the increasing SSA content in the geopolymeric mortars decreased the compressive strength for the first and last curing ages. Although SSA had displayed a reactive and synergic behaviour in Portland cement systems in accordance with previous works $(22,28)$, it showed different behaviour in the alkali-activation system. According to Cheng et al. (39), MK-based geopolymer develops high compressive strength, mainly because of the large surface area and high reactivity of MK, which lead to greater geopolymerization due to increasing dissolved aluminosilicate phases. Zhu et al. (40) evaluated the replacement of MK by other material as reactive as MK, in thermal-treated geopolymer production, that was RHA. According to the authors, a replacement content of MK by RHA in $20 \%$ offered a significant compressive strength enhancement around $62.5 \%$ and $21.7 \%$ at 7 and 28 curing days at $50^{\circ} \mathrm{C}$, respectively. In such a study, the compressive

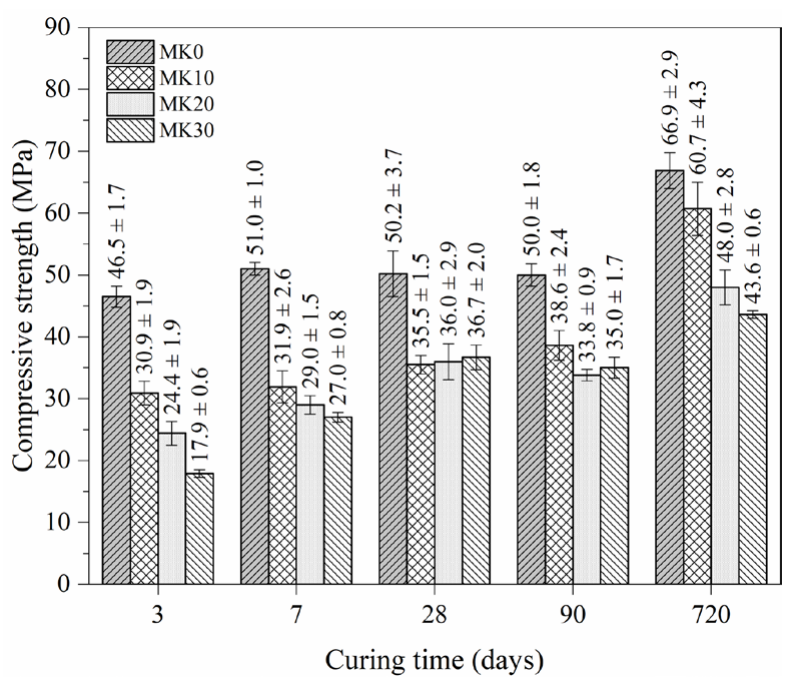

FiguRE 4. Compressive strength of the SSA/MK-based geopolymeric mortars with different SSA contents $(0 \mathrm{wt} . \%$ - MK0; 10 wt. $\%$ - MK10; 20 wt. $\%$ - MK20; 30 wt. $\%$ - MK30) cured at $25^{\circ} \mathrm{C}$ from 3 to 720 days. 


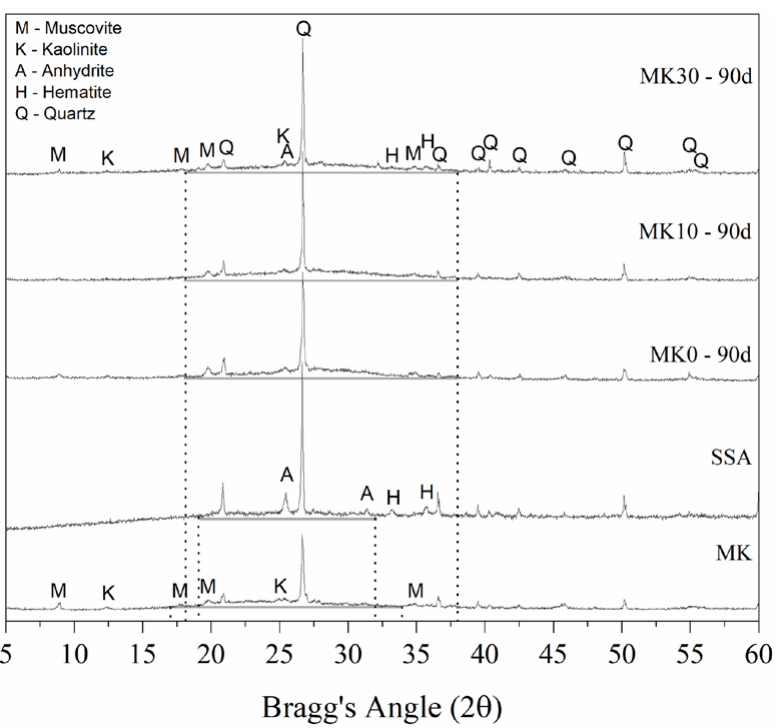

FIGURE 5. XRD patterns of precursors MK and SSA and the SSA/MK geopolymeric pastes with 0 wt.\% of SSA (MK0), 10 wt.\% of SSA (MK10) and $30 \mathrm{wt} . \%$ of SSA (MK30) cured at $25^{\circ} \mathrm{C}$ for 90 days. strength enhancements were attributed to the enrichment of the content and nature of the gel due to the dissolution of the silica from RHA. In this current work, increasing MK replacement with SSA, that presented a lower content of amorphous phases containing alumina and, mainly, silica compared to MK, reduces compressive strength likely due to a sum of a dilution effect and a changing of the nature of the gel formed, which could occur when the $\mathrm{SiO} / \mathrm{Al}_{2} \mathrm{O}$ and $\mathrm{Na}_{2} \mathrm{O} / \mathrm{Al}_{2} \mathrm{O}_{3}$ ratios of the system are changed (41). Such effects could explain the decrease of the compressive strength higher than the MK replacement percentage in the mortars. However, at intermediate curing times, the increasing SSA content had no significant effect on compressive strength.

Although a partial MK replacement with SSA lowered the geopolymerization rate, the reaction progressed for an extended duration. The geopolymerization progress was clearly identified by an increasing compressive strength gain by rising the SSA content between 3 and 720 days. The compressive strength gain was $96.4 \%, 96.7 \%$ and $143.6 \%$

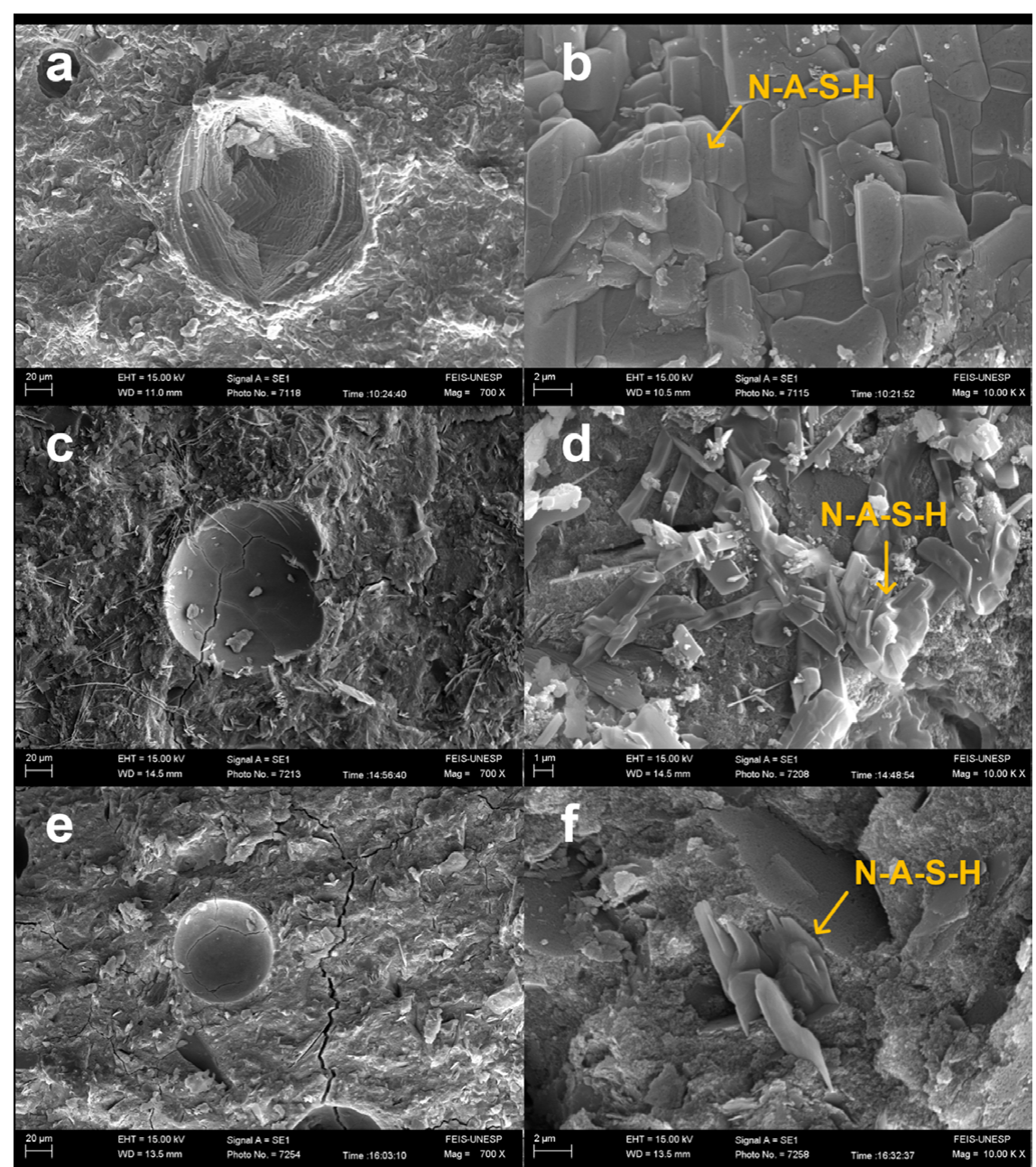

FIGURE 6. SEM Micrographs of the MK/SSA geopolymeric pastes with $0 \mathrm{wt} . \%$ of SSA (MK0, a and b), $10 \mathrm{wt} . \%$ of SSA (MK10, c and d) and $30 \mathrm{wt} . \%$ of SSA (MK30, e and f) cured at $25^{\circ} \mathrm{C}$ for 90 days. 
for geopolymeric mortars MK10, MK20 and MK30, respectively, but was only $43.9 \%$ for MK0 for the same time frame. This behaviour means that the SSA reaction rate was slower than for $\mathrm{MK}$, and the geopolymerization process for SSA/MK systems required a longer curing time. Zhang et al. (42) studied the influence of MK replacement by fly ash on the reaction process in the MK-based geopolymers. According to the authors, the MK replacement of 10\% by fly ash increased the reaction extent due to the lower dissolution of fly ash compared to the MK. The results obtained in the study herein are endorsed by such a report.

\subsubsection{XRD analyses}

The XRD patterns of the geopolymeric pastes with an equivalent mix proportion of mortars MK 0 , MK10 and MK30 were determined at both 90 curing days and $25^{\circ} \mathrm{C}$. According to the XRD patterns in Figure 5, the crystalline phases of SSA were quartz ( $\mathrm{SiO}, \mathrm{PD}-$ Fcard\#331161), hematite ( $\mathrm{Fe}_{2} \mathrm{O}_{3}$, PDFcard\#130534) and anhydrite (CaSO, PDFcard\#371496), as mentioned previously in item 2.1.1, while those of MK were quartz $\left(\mathrm{SiO}_{2}\right.$, PDFcard\#331161), kaolinite $\left(\mathrm{Al}_{2} \mathrm{Si}_{2} \mathrm{O}_{5}(\mathrm{OH})_{4}, \mathrm{PDF}\right.$ card\#140164) and muscovite $\left(\mathrm{KAl}_{3} \mathrm{Si}_{3} \mathrm{O}_{10}(\mathrm{OH})_{2}\right.$, PDFcard\#210993). Regarding the XRD patterns of the geopolymeric pastes, all the pastes presented the same crystalline phases identified in the XRD pattern of the precursors because of the non reacted phases of MK and SSA. As reported by Belmokhtar (43), the structures of muscovite and quartz are not affected during geopolymeric, which means that those phases do not react and, conse- quently, do not offer any contribution to developing cementing gel. This result was corroborated by the compressive strength results: the samples containing SSA had lower compressive strengths because of the low reactivity of ash. In addition, in the XRD patterns of all samples containing SSA was not identified zeolite peaks, pointing out any zeolite formation from the geopolymer matrix, which could lead to compressive strength loss. Such a result endorses that the lower compressive strength of the samples MK10 and MK30 are more related to a dilution effect and a changing the nature of gel formed due to SSA addition.

Diffuse halo signals were noted at about $16^{\circ}-34^{\circ}$ and $19^{\circ}-32^{\circ}$ of the $2 \theta$ angle in the XRD patterns of MK and SSA, respectively, which indicated the presence of amorphous phases (44) in the composition of the precursors. These amorphous halo signals were displaced to $18^{\circ}-38^{\circ}$ in the XRD patterns of geopolymeric pastes MK0, MK10 and MK30. This displacement denoted the occurrence of a geopolymeric reaction, which yielded new amorphous phases as N-A-S-H gel $(34,44,45)$. When comparing the XRD pattern of pastes MK0 and the others containing SSA (MK10 and MK30), no significant difference was found for pastes MK10 and MK30, except for the remaining crystalline phases from SSA.

\subsubsection{SEM analyses}

The microstructural analyses were carried out using SEM characterization on pastes MK0, MK10 and MK30. Paste MK10 was chosen to be analysed

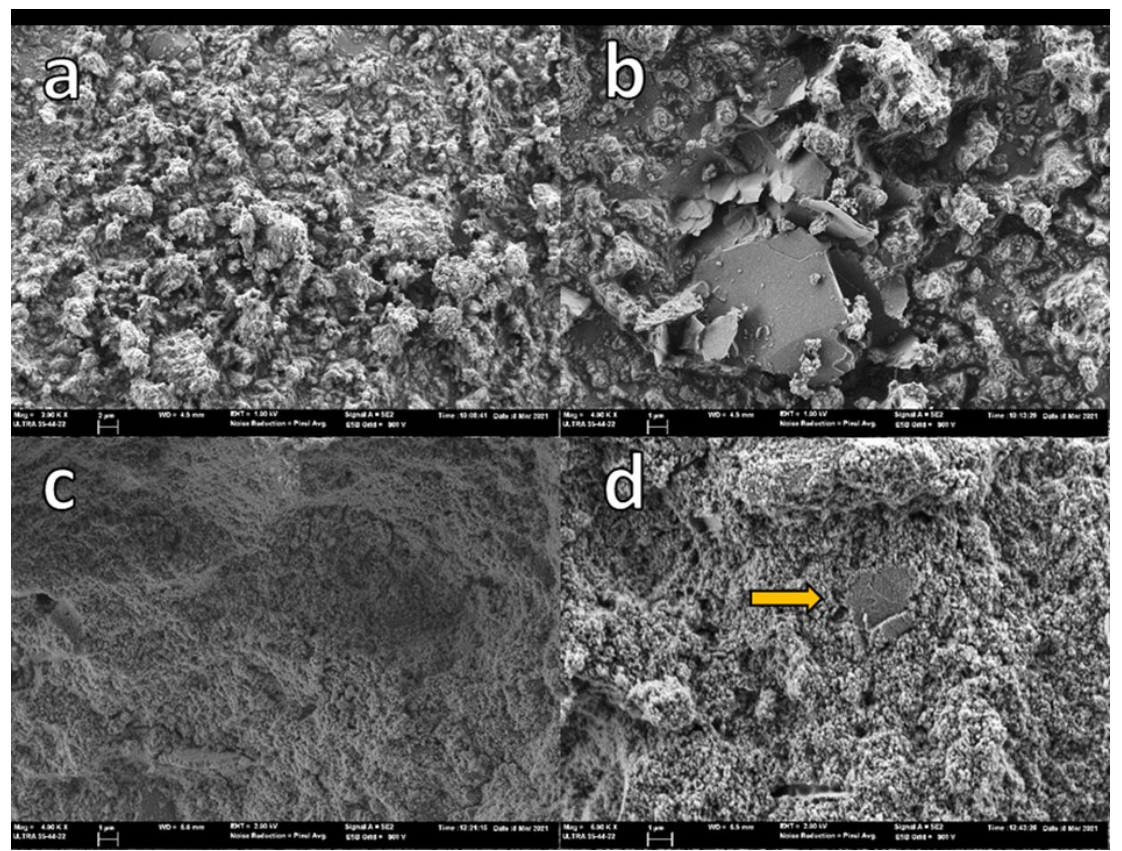

FIGURE 7. SEM micrographs: a SSA powder; b) plate-like particle in SSA; c) general view of the alkali activated SSA paste; d) detailed view of the binding N-A(F)-S-H gel and the reacted plate-like particle (see arrow). 
by SEM for its low SSA content, along with paste MK30 because it had the highest SSA content. The micrograph images of pastes MK0 were taken as the reference. The micrograph images of samples $\mathrm{MK} 0$, MK10 and MK30 at both 90 curing days and $25^{\circ} \mathrm{C}$ are presented in Figure 6. At a magnification between 700 and $10000 x$, geopolymeric pastes MK0, MK10 and MK30 presented a dense microstructure, described in the literature as the result of N-A-S-H type gel forming by a geopolymeric reaction (4648). The XRD analysis did not reveal the presence of zeolitic phases by the chemical evolution of N-A$\mathrm{S}-\mathrm{H}$ gel (30). The SEM micrographs confirmed the absence of crystalline zeolitic-type particles.

The non-formation of these zeolitic phases agrees with compressive strength increasing for long curing times $(30,49)$. There was a significant difference in the microstructure organisation among pastes MK0 (Figure 6a and 6b), MK10 (Figure 6c and 6d) and MK30 (Figure 6e and 6f). Many cementing particles (N-A-S-H type cementing gel) were observed for MK0 (Figure 6b). When a small amount of MK was replaced with SSA (MK10), the same type of particles were observed, but in smaller numbers (Figure $6 \mathrm{~d})$. These particles were bonded to the amorphous matrix (probably formed with N-A-S-H gel and the unreacted SSA particles). Finally, for sample MK30, fewer characteristic gel particles were observed in MK0 and the bonding matrix among them was larger. The changes in the microstructure of the cementing matrix of geopolymers due to the presence of SSA could explain the differences observed in mechanical strength development.

In order to analyze the potential contribution of SSA in the geopolymeric reaction, SSA-activated pastes were prepared (maintaining the same proportions in the activating solution and the activator/SSA ratio than those for MK/SSA systems previously described. A 28-days (room temperature cured) SSA activated paste was prepared and low strength was reached $(<10 \mathrm{MPa})$ : this value means that SSA had a limited reactivity in the activating conditions selected. However, there is a contribution to the development of binding gels. SEM micrographs of the SSA and the activated SSA samples were taken (Figure 7). Figure 7a shows the irregular morphology of SSA particles and figure $7 \mathrm{~b}$ shows the presence of platelet-like particles attributed to decomposed clay compounds. Figure $7 \mathrm{c}$ shows the microstructure of the binding gel formed by geopolymeric reaction; Figure $7 \mathrm{~d}$ shows a detailed microstructure of the N-A(F)-S-H gel (due to the presence of iron compounds in the SSA, the gel also contained this element) and a reacted plate-like SSA particle. The gel was formed by the agglutination of nanoparticles (less than $200 \mathrm{~nm}$ ) and its composition (EDS) presented a $\mathrm{SiO}_{2} /$ $\left(\mathrm{Al}_{2} \mathrm{O}_{3}+\mathrm{Fe}_{2} \mathrm{O}_{3}\right)$ molar ratio of 3.6 and $\left(\mathrm{Al}_{2} \mathrm{O}_{3}+\mathrm{Fe}_{2} \mathrm{O}_{3}\right)^{2} /$ $\mathrm{Na}_{2} \mathrm{O}$ molar ratio of 0.62 .

\section{CONCLUSIONS}

The aim of the paper was to evaluate the mechanical development of MK-based geopolymers containing SSA by microscopical and mineralogical analyses, and compressive strength development at long curing times. According to the results, the key conclusions were obtained:

- The SSA/MK-based geopolymeric mortars activated with an activating solution of $\mathrm{NaOH}$ and $\mathrm{Na}_{2} \mathrm{SiO}_{3}$ at a $\mathrm{NaOH}$ concentration of 8 mol. $\mathrm{kg}^{-1}$ $(\varepsilon=1.6)$ presented higher compressive strength.

- The geopolymeric mortars containing 10 wt.\% of SSA (MK10) had a compressive strength of $60.7 \pm 4.3 \mathrm{MPa}$ for 720 curing days at $25^{\circ} \mathrm{C}$, which was similar to the reference geopolymeric mortar (MK0), whose compressive strength was 66.9 $\pm 2.9 \mathrm{MPa}$ for the same curing conditions.

-Although SSA had a delaying effect on the mechanical development of the MK-based geopolymer, the compressive strength gain between 3 and 720 curing days at $25^{\circ} \mathrm{C}$ was maximum $(143.6 \%)$ in the sample with the highest SSA content (MK30) vs. $43.9 \%$ of the compressive strength gain for reference sample MK0.

- Although the increasing SSA content diminished the compressive strength of the geopolymeric mortars, all the evaluated SSA contents $(10,20$, $30 \mathrm{wt} . \%$ ) had a compressive strength over $40 \mathrm{MPa}$ for 720 curing days at $25^{\circ} \mathrm{C}$.

- The microstructure of the geopolymeric pastes containing SSA (10 and $30 \mathrm{wt} . \%$ ) was morphologically changed by the SSA incorporation in the geopolymer matrix. It presented fewer N-A-S-H type gel with morphology similar to the one observed for the reference geopolymer paste with MK only. Such behaviour was considered key to explain the differences in compressive strength development.

\section{ACKNOWLEDGMENTS}

This study was financed partly by the Coordenação de Aperfeiçoamento de Pessoal de Nível Superior - Brasil (CAPES) - (Finance Code 001 and CAPES/DGU n. 266/12), and the National Council of Scientific and Technological Development - Brasil (CNPq) - (n. 14/2013, process 478057/2013-0 and 309015/2015-4). The authors would like to thank Programa Institucional de Internacionalização - CAPES - PrInt. The authors acknowledge the Scanning Electron Microscopy Service of FEIS/UNESP, Serviço Municipal Autônomo de Água e Esgoto (SEMAE) from the São José do Rio Preto city - SP, Brazil and Diatom Mineração Ltda. The authors would like to thank Programa Institucional de Internacionalização CAPES - PrInt. 


\section{AUTHOR CONTRIBUTIONS}

Conceptualization: D. Istuque, L. Soriano, M.V. Borrachero, J. Payá, M.M. Tashima. Data curation: . Formal analysis: D. Istuque, M.V. Borrachero, M.M. Tashima. Funding acquisition: J. Payá, J.L. Akasaki, M.M. Tashima. Investigation: D. Istuque, L. Soriano, J.L. Akasaki, J.L.P. Melges. Methodology: D. Istuque, J. Payá, M.M. Tashima. Project administration: J. Payá, J.L. Akasaki, M.M. Tashima. Resources: J.L. Akasaki, J.L.P. Melges. Supervision: J. Payá, M.M. Tashima. Visualization: L. Soriano, M.V. Borrachero, J.L.P. Melges. Roles/Writing, original draft: D. Istuque, J. Payá, M.M. Tashima. Writing, review \& editing: D. Istuque, L. Soriano, M.V. Borrachero, J. Payá, J.L.P. Melges, M.M. Tashima.

\section{REFERENCES}

1. Gagg, C.R. (2014) Cement and concrete as an engineering material: An historic appraisal and case study analysis. Eng. Fail. Anal. 40, 114-140. https://doi.org/10.1016/j. engfailanal.2014.02.004

2. Mikulčić, H.; Klemeš, J.J.; Vujanović, M.; Urbaniec, K.; Duić, N. (2016) Reducing greenhouse gasses emissions by fostering the deployment of alternative raw materials and energy sources in the cleaner cement manufacturing process. J. Clean. Prod. 136 [B], 119-132. https://doi.org/10.1016/j. jclepro.2016.04.145.

3. Rahman, A.; Rasul, M.G.; Khan, M.M.K.; Sharma, S. (2014) Recent development on the uses of alternative fuels in cement manufacturing process. Fuel. 145, 84-99. https://doi. org/10.1016/j.fuel.2014.12.029.

4. Zhang, Z.H.; Zhu, H.J.; Zhou, C.H.; Wang, H. (2015) Geopolymer from kaolin in China: An overview. Appl. Clay. Sci. 119 [1], 31-41. https://doi.org/10.1016/j. clay.2015.04.023

5. Mejía-Arcila, J.; Valencia-Saavedra, W.; Mejía de Gutiérrez, R. (2020) Eco-efficient alkaline activated binders for manufacturing blocks and pedestrian pavers with low carbon footprint: Mechanical properties and LCA assessment. Mater. Construcc. 70 [340], e232. https://doi.org/10.3989/ mc.2020.17419.

6. Palomo, A.; Krivenko, P.; Garcia-Lodeiro, I.; Kavalerova, E.; Maltseva, O.; Fernández- Jiménez A. (2014) A review on alkaline activation: new analytical perspectives. Mater. Construcc. 64 [315], e022. https://doi.org/10.3989/ mc.2014.00314.

7. Provis, J.L.; Palomo, A.; Shi, C. (2015) Advances in understanding alkali-activated materials. Cem. Concr. Res. 78 [A], 110-125. https://doi.org/10.1016/j. cemconres.2015.04.013.

8. Shi, C.; Jiménez, A.F.; Palomo, A. (2011) New cements for the 21st century: The pursuit of an alternative to Portland cement. Cem. Concr. Res. 41, 750-763. https://doi. org/10.1016/j.cemconres.2011.03.016.

9. Vásquez, A.; Cárdenas, V.; Robayo, R.A.; Mejía de Gutiérrez, R. (2015) Geopolymer based on concrete demolition waste. Adv. Powder Technol. 27 [4], 1173-1179. https://doi. org/10.1016/j.apt.2016.03.029.

10. Part, W.K.; Ramli, M.; Cheah, C.B. (2015) An overview on the influence of various factors on the properties of geopolymer concrete derived from industrial by-products. Constr. Build. Mater. 77, 370-395. https://doi.org/10.1016/j. conbuildmat.2014.12.065.

11. Xie, T.; Ozbakkaloglu, T. (2015) Behavior of low-calcium fly and bottom ash-based geopolymer concrete cured at ambient temperature. Ceram. Int. 41 [4], 5945-5958. https://doi. org/10.1016/j.ceramint.2015.01.031.

12. Noor-ul-Amin; Faisal, M.; Muhammad, K.; Gul, S. (2015) Synthesis and characterization of geopolymer from bagasse bottom ash, waste of sugar industries and naturally available china clay. J. Clean. Prod. 129, 491-495. https://doi. org/10.1016/j.jclepro.2016.04.024.

13. Castaldelli, V.N.; Moraes, J.C.B.; Akasaki, J.L.; Melges, J.L.P.; Monzó, J.; Borrachero, M.V.; Soriano, L.; Payá,
J.; Tashima, M.M. (2016) Study of the binary system fly ash/sugarcane bagasse ash (FA/SCBA) in $\mathrm{SiO}_{2} / \mathrm{K}_{2} \mathrm{O}$ alkali-activated binders. Fuel. 174, 307-316. https://doi. org/10.1016/j.fuel.2016.02.020.

14. Rodríguez, E.D.; Bernal, S.A.; Provis, J.L.; Gehman, J.D.; Monzó, J.M.; Payá, J.; Borrachero M.V. (2013) Geopolymers based on spent catalyst residue from a fluid catalytic cracking (FCC) process. Fuel. 109, 493-502. https://doi.org/10.1016/j. fuel.2013.02.053.

15. Mellado, A.; Catalán, C.; Bouzón, N.; Borrachero, M.V.; Monzó, J.M.; Payá, J. (2014) Carbon footprint of geopolymeric mortar: Study of the contribution of the alkaline activating solution and assessment of an alternative route. $R S C A d v$. 4, 23846-23852. https://doi.org/10.1039/ c4ra03375b.

16. Ma, C-K.; Awang, A.Z.; Omar, W. (2018) Structural and material performance of geopolymer concrete: A review. Constr. Build. Mater. 186, 90-102. https://doi.org/10.1016/j. conbuildmat.2018.07.111.

17. Payá, J.; Monzó, J.; Borrachero, M.V.; Soriano, L. (2019) Sewage sludge ash. New Trends Eco-efficient Recycl. Concr. 121-152. https://doi.org/10.1016/B978-0-08-1024805.00005-1.

18. Vouk, D.; Nakic, D.; Stirmer, N.; Cheeseman, C.R. (2017) Use of sewage sludge ash in cementitious materials. Rev. Adv. Mater. Sci. 49, 158-170. Retrieved from https://www.ipme. ru/e-journals/RAMS/no_24917/05_24917 nakic.pdf.

19. Smol, M.; Kulczycka, J.; Henclik, A.; Gorazda, K.; Wzorek, Z. (2015) The possible use of sewage sludge ash (SSA) in the construction industry as a way towards a circular economy. J. Clean. Prod. 95, 45-54. http://doi.org/10.1016/j. jclepro.2015.02.051.

20. Cyr, M.; Coutand, M.; Clastres, P. (2007) Technological and environmental behavior of sewage sludge ash (SSA) in cement-based materials. Cem. Concr. Res. 37 [8], 1278-1289. https://doi.org/10.1016/j.cemconres.2007.04.003.

21. Lynn, C.J.; Dhir, R.K.; Ghataora, G.S.; West, R.P. (2015) Sewage sludge ash characteristics and potential for use in concrete. Constr. Build. Mater. 98, 767-779. https://doi. org/10.1016/j.conbuildmat.2015.08.122.

22. Baeza-Brotons, F.; Garcés, P.; Payá, J.; Saval, J.M. (2014) Portland cement systems with addition of sewage sludge ash. Application in concretes for the manufacture of blocks. J. Clean. Prod. 82, 112-124. https://doi.org/10.1016/j. jclepro.2014.06.072.

23. Chen, Z.; Poon, C.S. (2017) Comparative studies on the effects of sewage sludge ash and fly ash on cement hydration and properties of cement mortars. Constr. Build. Mater. 154, 791-803.https://doi.org/10.1016/j.conbuildmat.2017.08.003.

24. Monzó, J.; Payá, J.; Borrachero, M.V.; Girbés, I. (2003) Reuse of sewage sludge ashes (SSA) in cement mixtures: the effect of SSA on the workability of cement mortars. Waste Manag. 23 [4], 373-381. https://doi.org/10.1016/S0956053X(03)00034-5.

25. Pérez-Carríon M.T.; Baeza Brotons, F.; Garcés, P.; Galao Malo, O.; Payá Bernabeu, J. (2013) Potencial use of sewage sludge ash as a fine aggregate replacement in precast concrete blocks. Dyna-Colombia. 80 [179], 142-150.

26. Tarrago, M.; Garcia-Valles, M.; Aly, M.H.; Martínez, S. (2017) Valorization of sludge from a wastewater treatment plant by glass-ceramic production. Ceram. Int. 43 [1], 930 937. https://doi.org/10.1016/j.ceramint.2016.10.083.

27. Yusuf, R.O.; Noor, Z.Z.; Din, M.F.M.; Abba, A.H. (2012) Use of sewage sludge ash (SSA) in the production of cement and concrete - a review. Int. J. Glob. Environ. 12, 214. https://doi. org/10.1504/IJGENVI.2012.049382.

28. Pérez-Carrión, M.; Baeza-Brotons, F.; Payá, J.; Saval, J.M.; Zornoza, E.; Borrachero, M.V.; Garcés, P. (2014) Potential use of sewage sludge ash (SSA) as a cement replacement in precast concrete blocks. Mater. Construcc. 64 [313], e002. https://doi.org/10.3989/mc.2014.06312.

29. Yamaguchi, N.; Ikeda, K. (2010) Preparation of geopolymeric materials from sewage sludge slag with special emphasis to the matrix compositions. J. Ceram. Soc. Japan. 118 [1374], 107-112. https://doi.org/10.2109/jcersj2.118.107.

30. Istuque, D.B.; Reig, L.; Moraes, J.C.B.; Akasaki, J.L.; Borrachero, M.V.; Soriano, L.; Payá, J.; Malmonge, J.A.; 
Tashima, M.M. (2016) Behaviour of metakaolin-based geopolymers incorporating sewage sludge ash (SSA). Mater. Lett. 180, 192-195. https://doi.org/10.1016/j. matlet.2016.05.137.

31. Istuque, D.B.; Soriano, L.; Akasaki, J.L.; Melges, J.L.P.; Borrachero, M.V.; Monzó, J.; Payá, J.; Tashima, M. (2019) Effect of sewage sludge ash on mechanical and microstructural properties of geopolymers based on metakaolin. Constr. Build. Mater. 203, 95-103. https://doi. org/10.1016/j.conbuildmat.2019.01.093.

32. Khatib, J.M.; Baalbaki, O.; ElKordi, A.A. (2018) Metakaolin. In: Waste Supplem. Cement. Mater. Concr.: Charact. Prop. Applicat. 493-511. https://doi.org/10.1016/B978-0-08102156-9.00015-8.

33. UNE-EN 196-1 (2018), Methods of Testing Cement - Part 1: Determination of Strength. https://www.en-standard. eu/une-en-196-1-2018-methods-of-testing-cement-part-1determination-of-strength/.

34. Fernández-Jiménez, A.; Cristelo, N.; Miranda, T.; Palomo, Á. (2017) Sustainable alkali activated materials: Precursor and activator derived from industrial wastes. J. Clean. Prod. 162, 1200-1209. https://doi.org/10.1016/j.jclepro.2017.06.151.

35. Ozer, I.; Soyer-Uzun, S. (2015) Relations between the structural characteristics and compressive strength in metakaolin based geopolymers with different molar $\mathrm{Si} /$ Al ratios. Ceram. Int. 41 [8], 10192-10198. https://doi. org/10.1016/j.ceramint.2015.04.125.

36. Kuenzel, C.; Neville, T.P.; Donatello, S.; Vandeperre, L.; Boccaccini, A.R.; Cheeseman, C.R. (2013) Influence of metakaolin characteristics on the mechanical properties of geopolymers. Appl. Clay Sci. 83-84, 308-314. https://doi. org/10.1016/j.clay.2013.08.023.

37. Singh, N.B.; Middendorf, B. (2020) Geopolymers as an alternative to Portland cement: An overview. Constr. Build. Mater. 237, 117455. https://doi.org/10.1016/j. conbuildmat.2019.117455.

38. Granizo, N.; Palomo, A.; Fernandez-Jiménez, A. (2014) Effect of temperature and alkaline concentration on metakaolin leaching kinetics. Ceram. Int. 40 [7], 8975-8985. https://doi.org/10.1016/j.ceramint.2014.02.071.

39. Cheng, H.; Lin, K.L.; Cui, R.; Hwang, C.L.; Chang, Y.M.; Cheng, T.W. (2015) The effects of $\mathrm{SiO}_{2} / \mathrm{Na}_{2} \mathrm{O}$ molar ratio on the characteristics of alkali-activated waste catalystmetakaolin based geopolymers. Constr. Build. Mater. 95, 710 720. https://doi.org/10.1016/j.conbuildmat.2015.07.028.

40. Zhu, H.; Liang. G.; Zhang, Z.; Wu, Q.; Du, J. (2019) Partial replacement of metakaolin with thermally treated rice husk ash in metakaolin-based geopolymer. Constr. Build. Mater. 221, 527-538. https://doi.org/10.1016/j.conbuildmat.2019.06.112.

41. Sarkar, M.; Dana, K. (2021) Partial replacement of metakaolin with red ceramic waste in geopolymer. Ceram. Int. 47 [3], 3473-3483. https://doi.org/10.1016/j.ceramint.2020.09.191.

42. Zhang, Z.; Wang, H.; Zhu, Y.; Reid, A.; Provis, J.L.; Bullen, F. (2014) Using fly ash to partially substitute metakaolin in geopolymer synthesis. Appl. Clay Sci. 88-89, 194-201. https://doi.org/10.1016/j.clay.2013.12.025.

43. Belmokhtar, N.; Ammari, M.; Brigui, J.; Allal, B.L. (2017) Comparison of the microstructure and the compressive strength of two geopolymers derived from Metakaolin and an industrial sludge. Constr. Build. Mater. 146, 621-629. https:// doi.org/10.1016/j.conbuildmat.2017.04.127.

44. Aboulayt, A.; Jaafri, R.; Samouh, H.; Cherki, El Idrissi, A.C.; Roziere, E.; Moussa, R.; Loukili, A. (2018) Stability of a new geopolymer grout: Rheological and mechanical performances of metakaolin-fly ash binary mixtures. Constr. Build. Mater. 181, 420-436. https://doi.org/10.1016/j. conbuildmat.2018.06.025.

45. Timakul, P.; Rattanaprasit, W.; Aungkavattana, P. (2016) Improving compressive strength of fly ash-based geopolymer composites by basalt fibers addition. Ceram. Int. 42 [5], 6288-6295. https://doi.org/10.1016/j.ceramint.2016.01.014.

46. Tchakouté, H.K.; Rüscher, C.H.; Kong, S.; Kamseu, E.; Leonelli, C. (2016) Geopolymer binders from metakaolin using sodium waterglass from waste glass and rice husk ash as alternative activators: A comparative study. Constr. Build. Mater. 114, 276-289. https://doi.org/10.1016/j. conbuildmat.2016.03.184.

47. Wan, Q.; Rao, F.; Song, S.; García, R.E.; Estrella, R.M.; Patiño, C.L.; Zhang, Y. (2017) Geopolymerization reaction, microstructure and simulation of metakaolin-based geopolymers at extended $\mathrm{Si} / \mathrm{Al}$ ratios. Cem. Concr. Compos. 79 , 45-52. https://doi.org/10.1016/j.cemconcomp.2017.01.014.

48. Moraes, J.C.B.; Tashima, M.M.; Akasaki, J.L.; Melges, J.L.P.; Monzó, J.; Borrachero, M.V.; Soriano, L.; Payá, J. (2017) Effect of sugar cane straw ash (SCSA) as solid precursor and the alkaline activator composition on alkali-activated binders based on blast furnace slag (BFS). Constr. Build. Mater. 144 214-224. https://doi.org/10.1016/j.conbuildmat.2017.03.166.

49. Król, M.; Rożek, P.; Chlebda, D.; Mozgawa, W. (2019) ATR/ FT-IR studies of zeolite formation during alkali-activation of metakaolin. Solid State Sci. 94, 114-119. https://doi. org/10.1016/j.solidstatesciences.2019.06.004 